Gaálné Szabó Edith

\title{
SZUBURBANIZÁCIÓS FOLYAMATOK ÉS TÁRSADALMI KONFLIKTUSOK MAGYARORSZÁGON A RENDSZERVÁLTÁS UTÁN
}

\begin{abstract}
Research carried out this far in Hungary focusing spatial structures were mainly displayed concerning settlements struggling with poverty. Lately, these works have been expanded to examine settlements which are beneficiary of the process of suburbanization.

Mostly young citizens with higher social status move into these suburban settlements escalating the number of conflicts with the native inhabitants. Local communities weaken as the newcomers grow in number seeking primarily self-realization or recreation purposes. The exposing social tensions are substantially similar to the axiological characteristics change occurred during the second demographic transition. Beyond the heterogeneous demographic characteristics of the native inhabitants and the immigrants, politics deepens these conflicts by acting on self-interest in these suburban settlements.

This paper aims to demonstrate the process of suburbanization by analysing the literature review of the centre-periphery model applied on the Hungarian settlement patterns, revealing the local challenges of two suburban settlement: Budajenő and Tinnye. Exploring and understanding the conflicts caused by segregation and migration on suburban settlements may aid us resolve or ease those tensions.
\end{abstract}

\section{Bevezetés}

Magyarországon a térszerkezeti változások kérdéseivel kapcsolatos kutatások nagyrészt a szegénységgel küzdő települések kapcsán kerülnek bemutatásra. Az utóbbi években azonban egyre jobban kiterjednek a vizsgálódások azokra a településekre is, amelyek a térbeli átalakulások következtében nyertesei a szuburbanizációnak (Koós 2020).

A magasabb státuszú, többnyire fiatal népesség elővárosokba való költözése után a lokális konfliktusok megsokasodtak (Kovács 2017). A helyi közösségek meggyengülnek, helyüket az önmegvalósítást és a kényelmes életmódot kereső lakosok közössége veszi át, kiváltképpen a rekreációs szuburbán településeken. A kibontakozó társadalmi konfliktusok a második demográfiai átmenet ${ }^{79}$ mögötti változások lényegi jegyeit is idézik. A történelmileg meghatározott és a beköltöző lakónépesség összetételének különbözőségein túl a döntéshozók érdekeit szolgáló intézkedések tovább mélyítették a feszültséget a szuburbán településeken.

\footnotetext{
${ }^{79}$ https://www.demografia.hu/hu/tudastar/fogalomtar/14-masodik-demografiai-atmenet A második demográfiai átmenetet jellemző értékváltozások nem kerülnek feldolgozásra a tanulmányban, azonban azoknak a társadalmi csoportoknak a problémakörét tárja fel, akik többnyire annak résztvevői.
} 
A tanulmány a magyar településszerkezet centrum-periféria modell változásait vizsgáló szakirodalmakon keresztül mutatja be a szuburbanizációs folyamatokat, illetve két nyertes szuburbán település: Budajenő és Tinnye lokális problémáit. A szegregáció és migráció jelensége nyomán kialakuló konfliktusok megismerése, okainak értelmezése hozzájárulhat azoknak feloldásához a szuburbán településeken.

\section{A szuburbanizáció jellemzői Magyarországon}

Az urbanizáció, mint a szuburbanizációt is magába foglaló jelenség megkésve jelentkezett Magyarországon. A fejlett országokban 1930 és 1960 között lezajlott az urbanizációs folyamatok nagy része, míg Magyarországon ekkor kezdett el kibontakozni az iparosodás és a jelentősebb gazdasági fellendülés következtében. 1990 után a népesség migrációja már nem a falvakból a városokba történt, hanem a nagyobb városokból az azokat körülvevő falvakba (Enyedi 1988).

A magyar nagyvárosi térségek szerkezeti változásaiból fakadó sajátosságokat és hatásokat feltáró hazai kutatásaiban Szirmai bemutatja a 2005, illetve 2014-es években elvégzett, 100000 fót meghaladó reprezentatív népesség vizsgálata ${ }^{80}$ során a magyar urbanizáció főbb jellegzetességeit. A 2005-ös kilenc nagyváros-térségi vizsgálatnak eredménye azt mutatja, hogy új sajátosságok kezdenek megjelenni a magyarországi társadalmi strukturális átalakulások következtében. A kutató elsősorban a csökkenő presztízsű belvárosokról, a nagyvárosok külső épülő részein új lakónegyedekről számol be (Szirmai 2015). A hagyományos centrum-periféria struktúra részben megerősödött, részben átszerveződött. A megerősödést az mutatta, hogy a várostérségek belső szerkezetében megváltozott a strukturális hierarchia. A magas státuszú képzett munkaerő a városokban koncentrálódott, a vidéken pedig jellemzően a képzetlenek laktak. A fejlett városrészekre az infrastruktúra fejlődése, ill. a magasabb iskolai végzettségüek nagyobb számban való megjelenése volt jellemző, míg a vidéken ellenkező folyamatok zajlottak le. A Tárki 2014 -es kutatásaiban ${ }^{81}$ is a rendszerváltás hatásainak megítélése szempontjából a magasabb iskolai végzettségűek érvényesülését láthatjuk. Magyarországon, bár elkezdődött a centrum-periféria modell szerkezeti átalakulása, de mégsem lehetett attól teljesen eltekinteni: ez a jelenség a kettős hierarchikus területi társadalmi struktúra nevet kapta (Szirmai 2009). A várostérségekben magas státusú centrum és alacsony státusú periféria csoportok alakultak ki, ugyanakkor az alacsony státusú centrum és a magas státusú periféria is megtalálható. Ezek arányai megtörték a centrum és a periféria között húzódó térbeli társadalmi lejtőt.

Szirmai 2014-es várostérségi társadalom-szerkezet vizsgálata a 2005-ös vizsgálat alapján, annak megismétléseként készült. A várostérségi különbségek elkezdtek kiegyenlítődés mutatni társadalmi szerkezetében, azonban a város és környéke közötti

\footnotetext{
${ }^{80}$ https://mek.oszk.hu/15300/15390/15390.pdf (147-164).

${ }^{81}$ https://www.tarki.hu/hu/news/2014/kitekint/20140224_rendszer.html
} 
társadalmi különbség fokozódott. E jelenség által egy újfajta, belső szuburbanizációo ${ }^{82}$ kezdett kibontakozni (Szirmai - Váradi 2012).

\section{A szuburbanizáció nyertesei és vesztesei}

A rendszerváltáskor végbemenő ideológiai, politikai, gazdasági átalakulás jelentősen meghatározta az ország térbeli változásait. A piacgazdaság átvette a központi források helyét, a szolgáltatóipar és a magánvállalkozók előtérbe kerülve maguk mögé utasították a gyáripart, illetve a hagyományos nehézipart (Valuch 2014). Magyarországon a piacgazdaság feltételeinek megjelenését követően az elővárosi fejlődés többféle formában nyilvánult meg. Azok a települések, amelyek fel tudtak zárkózni a gazdasági és piaci változásokhoz, valamint a szolgáltatói iparhoz is tudtak kapcsolódni nyertesként kerültek ki az átmeneti időszakból. Ugyancsak a szuburbanizáció nyerteseiként említhetők a szerényebb anyagi eszközökkel rendelkező fiatal, kisgyermekes házaspárok által lakott települések is, akik (települések?) számára vonzó környezetet jelentett a hétvégi házas környék, még a hiányos infrastruktúra ellenére is. A nyugdíjas korosztályból is sokan igénybe veszik azt a lehetőséget, hogy a gyerekekre hagyják városi házaikat, maguk pedig kiköltöznek a városon kívül (Szirmai 2015).

A nyertes településeken kívül a megjelenő lakásprivatizációval egyidejüleg a szuburbanizációs folyamatok azonban tovább erősítették a szegregált negyedek kialakulásának folyamatát. Így a területi egyenlőtlenségek következtében nem csak nyertes, hanem vesztes településekről is beszélhetünk. Ezeken a településeken a rendszerváltástól várt társadalmi jóllét helyett a munkanélküliség, a társadalmi mobilitás nehézségei, a növekvő egyenlőtlenségek, valamint a szociális biztonság csökkenése fokozódtak. Az egyre jobban differenciálódó jövedelmek következményeként a magyar városokban megfigyelhető volt mind a magas státuszú lakónegyedek elszaporodása, mind pedig az alacsony státuszú népesség szegregációja.

A szuburbanizáció területi egyenlőtlenségeinek kiváltó okait a városi népesség decentralizációjának térbeli megjelenése, szereplői és problémái magyarázzák. A szuburbanizáció, mint decentralizációs folyamat a megyeszékhely-nagyságú városok körül elsősorban a lakásproblémákból adódóan jelentkezett (Timár 1999). Ezzel együtt az önkormányzati autonómia fokozta az elővárosi fejlődés különbségeit. Az egyes önkormányzatok szuburbanizációval kapcsolatos állásfoglalása, fejlesztési gyakorlata a teljes elutasítástól a közömbösségen át az aktív támogatásig terjedt. Voltak olyan települések, ahol az önkormányzat forráshiánya vezetett ahhoz, hogy a testület néhány telek vagy készpénz fejében ingatlanfejlesztő cégeknek adta át fejleszthető területeit (Dövényi - Kovács 1999). A tulajdon privatizációja, a piaci viszonyok térnyerése, a modernizáció, a vezetési elképzelések eredményei megnyilvánultak a települések lokális konfliktusaiban is. Gergely Júlia 2014-ben a budapesti agglomeráció néhány településén végzett kutatása alapján készült esettanulmány a településvezetők szerepét mutatja be a szuburbanizációs folyamatokat kísérő helyi problémák alakulásában (2014). Gergely szerint nem bír olyan vonzerővel a városkörnyéki térség már, mint a rendszerváltást követően, amely elsősorban a családok romló anyagi helyzetével

\footnotetext{
${ }^{82}$ A városok külső övezeteiben épült új lakónegyedekbe áramlottak ki a belső részekben élő, magasabb státusú társadalmi rétegek, mintegy egy új migrációs hullámot hozva létre.
} 
magyarázható. A kiköltözési szándék csökkenésének oka elsősorban gazdasági kérdés. Az adósságok, valamint az alacsony iskolai végzettségü csoportokban lehetetlenné válik a mobilizáció. A kiköltözési szándék csökkenése kevésbé mutatható ki a magas státuszú, magas iskolai végzettségüeknél, akiknek az anyagi korlátok nem szabnak határt jelentősen a térbeli elmozdulásaikban. A rendszerváltást követő lakásprivatizáció, az ingatlan beruházások és fejlesztések teret adtak a szegregációs folyamatok kiteljesedésének, melyek településenként és régiónként különböznek egymástól. Megfigyelhető a keleti és nyugati városok mentén élők között is a gazdasági különbség. A nyugati régióban nagyobb a lakosságszám, magasabbak a jövedelmek, nagyobb családi házakban laknak, jobban felszereltek a háztartások, mint a keleti országrészben, mely mind azt bizonyítja, hogy a tőkeerő meghatározója a területi szuburbanizációnak (Bajmócy 1999).

Az újonnan kialakuló jogi szabályozás és a vezetési koncepciók a területi egyenlötlenségeket és az abból fakadó problémákat tovább mélyítették a szuburbán településeken (Timár 2006). Kondor 2016-os, a budapesti agglomeráció tíz településén végzett kutatásai alapján arra a következtetésre jutott, hogy a magántulajdon és az állami tulajdon egyensúlyának kérdései határozzák meg a területi egyenlőtlenségek alapját, amely számos konfliktus forrásává is válthat. A kialakuló konfliktusok megoldásában azonban az állam minimális szerepet vállal Magyarországon. A szuburbanizáció térhódításának köszönhetően a mezőgazdasági területek csökkennek, a beköltözők nem érdekeltek a föld termelőeszközként való megtartásában. Az ingatlanpiac kialakulásával az üdülő övezetek felértékelődtek, és az ország számos helyén rekreációs szuburbanizáció valósul meg (Kondor 2016).

Legnyilvánvalóbb nyereségnek az érintett falvak népességének gyarapodása, fiatalodása látszik, különösen ott, ahol erre másként nincs lehetőség (Gergely 2014).

\section{Társadalmi konfliktusokat felerősítő szuburbanizációs folyamatok}

A lakóhelyi mobilitás a gazdaságilag fejlett városok környékén, kiemelkedően Budapest agglomerációs övezetében volt jellemző (Schuchmann 2013). A lakosság térbeli helyzetének megváltozása, elmozdulása konfliktushelyzetet hoz létre, amely formálja a társadalom hagyományos rendszereit, viszonyait és identitását (Kovács 1999). Az elővárosokban megvalósuló szegregáció figyelhető meg a magyar térfolyamatokban (Vasárus 2017). A szegregáció magával vonja a dzsentrifikáció kedvezőbb területeken való megjelenését. Az így kialakuló lakóhelyi szegregációt elösegíti a kapcsolati háló szerepe is, különösen a hasonló anyagi forrásokkal rendelkezők esetében. A közeli kapcsolatban állók ugyanarra a településre költöznek, vagy ugyanabba az utcába, ezáltal is fokozva a térbeli elkülönülést (Bajmócy 2000 - Vasárus 2017).

Olyan esettanulmányok eredményeire tudunk támaszkodni, amelyekben a szuburbanizáció migrációs és szegregációs hatásait figyelhetjük meg. A nagyobb és gazdagabb ingatlanok tulajdonosai a magas presztízsű külvárosi településekre költöznek. Telkiben például a kilencvenes évek első felében telket vásárló és építkező új lakosok túlnyomó többsége a XI., XII., II. kerületből érkezett a faluba (Kovács 1999). A kapitalista viszonyok között kibontakozó elővárosi fejlődés jelentős szegregációhoz vezetett. 
A térbeli egyenlőtlenségekből fakadó társadalmi problémák meghatározzák a kialakuló helyi konfliktusok jellegét is (Boros 2011). A szuburbanizáció térhódítása után megjelenő problémák gyors ütemben szaporodni kezdtek, a helyi érdekellentétek kialakulása során sérülhettek a tulajdonrészek. Telekiben például az ötéves moratórium alatt álló kárpótlási földek tulajdonosainak követelniük kellett földjeik belterületbe vonását. Egy másik probléma az összeférhetetlenség volt az önkormányzatok ingatlanpiaci szerepvállalása során. De problémák jelentkeztek a helyi társadalom csoportjai között is, ugyanis a helyi társadalmi struktúra átalakulása során a politikai és értelmiségi életbe az újonnan betelepülők befogadása vagy kirekesztése egyaránt megjelent a szuburbán településeken. Fontos konfliktusforrás ezeken a településeken még a zöldövezetek gyors felszámolása, a terjeszkedés és a környezetszennyezés kérdése is (Molnár 2005).

\section{Szegregáció és konfliktusok Tinnyén a régi és új lakosok között}

A budapesti agglomeráció településein, a szuburbanizációt követő jelenségek és azok hatásainak vizsgálatai közül kiemelkedőek Molnár Mária 2005-ben végzett kutatásai (2005). A szerző a városból való kiköltözés hatására létrejövő változásokat vizsgálta Tinnyén, ahol a szuburbanizációt kísérő szegregáció jelentősen meghatározta a településen élők problémáit.

A zsámbéki medence észak-nyugati sarkában elhelyezkedő falu a Pilisi medence közvetlen szomszédságában, a budapesti agglomerációban található. A település térbeli és természeti környezete, valamint infrastrukturális jellemzői az egyes társadalmi csoportok szegregált elhelyezkedését mutatják be. A falu lakói a települést elválasztó patak mentén telepedtek le, a föutcája csak később alakult ki a kereskedelmi és közigazgatási szempontoknak megfelelően. A patak két partján helyezkedik el a Gazdasor, vagyis az Alsósor és a Túlsósor. Az Alsósortól induló dombon van az Urak sora, amely a mai főutca, ahol a 19. században kúriák épültek, mint ahogy ez a nevében is érzékelhetö. Itt található a katolikus templom, középületek, boltok, kocsma és a Népház is. A főutca végén a zsidók utcája helyezkedik el, ahol a zsidó családok nagy része telepedett le és zsinagóga is épült itt. A telkek nem zártak, hanem önálló területen figyelhetőek meg, amelyek részei a földrajzi tájnak. A szétdarabolt falu képe a térbeli szegregációt jeleníti meg. Míg a régi településszerkezet kialakulásában a gazdálkodási szempontok és a rokonsági kapcsolatok voltak a meghatározóak, addig a jelenlegi kapcsolódási pontok főként a középületek, közintézmények és a hozzájuk vezető utakon keresztül tárulnak fel. A településen mind a falusias, mind pedig a kisvárosi jellegzetességek megjelennek.

A falu közlekedési viszonyai kedvezőtlenek a budapesti agglomerációban, azonban a települések közötti kapcsolatai többirányúak a gazdasági érdekeknek megfelelöen. Elmondható az, hogy a gazdasági, földtulajdoni helyzet határozta meg az új beköltözők letelepedésének helyszínét, meghatározva ez által a településszerkezetet, azon belül pedig a szegregációt. A közlekedés gyors javulására nem lehetett számítani, így a migráció és ingázás nem volt jellemző a falura. Akik ingáztak, egy idő után elköltöztek a hiányos infrastruktúra miatt.

A szegregáció jelenségét tovább mélyíti a faluba költöző népesség cseréje. A 20. század történelmi eseményei nyomán a holokauszt következtében alig maradt zsidó család Tinnyén, házaikba régi gazdacsaládok leszármazottai, valamint különböző rétegekből érkezők költöztek, nagyon szegény vagy cigány családok. A házak tulajdonosainak cseréje után a Gazdasor 
elhanyagolt lett, a házakat nem újították fel, nyaralókként funkcionáltak. Majd 1990-ben új vásárlók települtek be a faluba, akik felújították az általuk megvásárolt házakat, később pedig új, modern épületek is megjelentek. Tinnyén ez a folyamat a 90 -es évek második felében indult el (Váradi 2000).

A falu alapnépessége vallását tekintve református ősközösség, akikhez zsellércsaládok települtek be. Mikor? Időbeli zavart okoz. 1990 és 2002 között a község lakossága 168 új lakost fogadott be és 48 új ház épült (Molnár 2005). A településen élőkre jellemző az, hogy a települést, azon belül pedig az elhelyezkedést személyes kapcsolatok határozzák meg (Bajmóczy 2000). Hasonló társadalmi státusszal rendelkező ismerős családok ugyanabba az utcába költöznek, mintegy zárt szegregált területet alakítva ki (Zsidók utcája vagy Urak sora).

A hagyományok nagyon erősen élnek a meglévő helyi kultúrákban. A faluban élők két csoportra osztották magukat: az igazi tinnyeiek és az idegenek, amely tényt mindkét csoport tudomásul vett. Igazi tinnyeiek azok a családok, akiket a falu annak elismer. Ennek fö meghatározó szempontja valamely vallási csoporthoz, illetve a régi lakosok által valamely jól ismert családhoz, rokonságához való tartozás. Ezek az ismert családok egyre kevesebben vannak a faluban, főként képviselők, vállalkozók, értelmiségi családok. Ök őrzik a falu hagyományait az új beköltözőket figyelemmel kísérve, illetve tájékoztatják őket írásban és szóban is a helyi szokásokról. Az újonnan beköltözők többnyire értelmiségi fiatal családok, akik nem tudtak, vagy nem akartak azonosulni a helyi kultúrával, szokásokkal.

Fontos szerepet töltenek be a kapcsolatteremtésben a formális és informális közösségek. Rajtuk keresztül bontakoznak ki azok a társadalmi konfliktusok a régi és az új lakosok között, amelyek meghatározzák a falu arculatát, kapcsolatrendszerét. A területileg elkülönült falurészek között gyenge a kooperáció, a kapcsolati háló, amely megosztja a falu egységét. A kiköltöző családok közül sokan csalódottak, az áhított nyugalom helyett cserébe zajos ${ }^{83}$ a környezet, különösen az újonnan kialakított utcákban. A polgármesteri hivatal munkájába nemcsak az igazi Tinnyeiek, hanem a beköltözők is kezdenek bekapcsolódni, ami feszültséggel járt. Erős elköteleződés van a régi lakosok között a családtagjaik iránt, ami a demokratikus vezetésnek nem enged teret. Megjelennek feszültségek a vallási csoportokban és a civil szervezetekben. A katolikus egyházközségi tanács jelentősen megváltozott, csak új beköltözők képviseltetik magukat, egy régi tagot leszámítva. A civil szervezetekben is csaknem teljesen kiszorulnak soraikból a régi lakosok, akiknek érdekérvényesítő képessége alacsonyabb, mint az idegeneknek. Mindennapi nézeteltérések jelentkeznek a munkavállalás, gyermeknevelés kérdéseiben is. Vannak a beköltözők között olyanok, akik átveszik a falu értékrendjét és szokásait, míg mások elkülönülnek. Ök csak kikapcsolódni, csendességet keresni költöztek ki, azonban életmódjukban még mindig a fővároshoz kötődnek. A természet szeretete, értékeinek megőrzése, valamint a régi paraszti kultúra megtartása nem ugyanazt jelenti a régi és az új lakosok számára.

\section{Migráció és társadalmi konfliktusok Budajenőn}

\footnotetext{
${ }^{83}$ Hulladék feldolgozó üzem közelsége és zaja.
} 
Kiss Réka 2005-ben végzett kutatásaiban Budajenőn 70 napig tartó terepmunka során igyekezett feltárni azt, hogy a kutatás előtti tíz évben megindult szuburbanizációs folyamatot kísérő migrációs jelenség milyen változásokat okozott a falu társadalomszerkezetében. A szerző a megfigyelés és interjúkészítés eszközeivel dokumentálta a jelentősebb közösségi alkalmak $^{84}$ tapasztalatait. Vizsgálta azt, hogy a lakosok cserélődése hogyan írta át az egyéni és közösségi kapcsolatrendszereket, a kulturális, és mentalitásbeli jellemzőket. A kutatás során felszínre kerültek a régi és új lakosok közötti társadalmi konfliktusok, amelyek elsősorban a kulturális szokások különbözőségében rejlettek, valamint a földtulajdon kérdései, illetve a politikai részvételben megjelenő nézeteltérésekben nyilvánultak meg.

Budajenő Pest megyében a Zsámbéki medence keleti részén, a Budai helység lábánál helyezkedik el, kiváló természeti környezetben, 2008-tól Magyarország legfejlettebb kistérségének tagjaként. A falu 2001-ben 1300 fős lakosságával a közepes népességű falvak sorába tartozott. Lakosságának korösszetétele 2005-ben az országos átlagnál kedvezőbben alakult: a 15 év alattiak aránya 17,6\%, a 40 év alattiak aránya 57,7\% volt, amely tükrözi a szuburbanizáció során tapasztalható migráció következtében a fiatalabb korúak dominánsabb megjelenését a faluban. Az 1930-as népszámláláskor Budajenő lakosságának 90\%-a német anyanyelvűnek vallotta magát. A második világháborút követően a német lakosság kitelepítése után szinte nem maradtak a faluban német anyanyelvűek, amely a falu etnikai térképét gyors ütemben átírta. A kitelepített német lakosok helyére székely parasztok, illetve alföldről érkező magyarok költöztek be. Így a falu élete egy konfliktusoktól és neheztelésektől megterhelt német- székely- magyar viszonyrendszerben folyt tovább, eltérő kulturális háttérrel.

A szuburbanizáció során elindult migrációs hullám az 1990-es években Budajenőn megduplázta a falu lakosságát. Ez a folyamat meghatározta a falu teljes demográfiai, környezeti és kulturális arculatát. Budajenő magas presztízsű szuburbán községnek számított a budapesti agglomerációban.

A településen kétfázisú migráció figyelhető meg:

1. 1990-es évek első felében a sok gyermekes alsó középosztálybeli családok költöztek ki, vállalva akár a nehéz életkörülményeket.

2. 1990-es évek második felében a gazdag, szellemi elithez tartozó középosztálybeli családok költöztek ki, akik a zöldövezeti luxust kedvelö, kiépített környéket választották lakóhelyül-

A migrációs hullámot követően a falu hagyományos élete kezdett átalakulni: a mezőgazdaság és az állattartás minimumra csökkent a faluban, a lakosság 80\%-a ingázott, igen magas volt az értelmiségi népesség száma (54\%) (Beluszky 2011). A falu központját kevésbé érintette a beköltözők általi változás, mivel az új lakosok jellemzően a falu külső zónáira jellemző luxus körülmények közé költöztek be. Ezek a luxus-negyedek gyakran a

\footnotetext{
${ }^{84}$ Olyan eseményeket vett megfigyelés alá, mint a Szent Márton napi lámpagyújtás, betlehemezés, helyi civil kezdeményezések stb.
} 
belterületekbe vonást eredményezték és a mezőgazdasági földeknek a felszámolását, amely veszélyeztette a régi falukép megmaradását, elősegítve jellegének elvesztését. Bár a falu aktuális vezetői törekedtek a természeti és kulturális örökség megtartására, az mégsem vezetett eredményre.

\section{1. táblázat: A bemutatott szuburbán településeken megjelenő társadalmi problémák a rendszerváltás után}

\begin{tabular}{|c|c|c|}
\hline & Tinnye & Budajenő \\
\hline 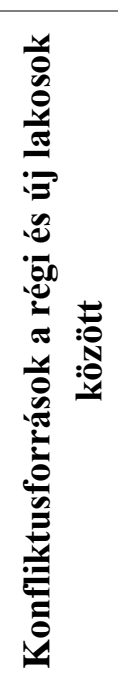 & $\begin{array}{c}\text { etnikai-kulturális } \\
\text { különbözőségek } \\
\text { gazdasági-hatalmi érdekek } \\
\text { infrastrukturális hiányosságok } \\
\text { környezeti zsúfoltság, zaj } \\
\text { térbeli szétdaraboltság } \\
\text { kevés munkalehetőség } \\
\text { alacsony civil érdekérvényesítés } \\
\text { faluvezetés családi } \\
\text { hagyományozása } \\
\text { alacsony beilleszkedési } \\
\text { hajlandóság }\end{array}$ & $\begin{array}{l}\text { földterületi viták belterületbe } \\
\text { vonás és értékesítés- kifizetés } \\
\text { ütemezési konfliktusok } \\
\text { vállalkozói lehetőségek } \\
\text { versenye } \\
\text { kulturális értékek } \\
\text { különbözősége } \\
\text { természeti környezet } \\
\text { megtartása körüli viták } \\
\text { hagyományos élet átalakulása, } \\
\text { korábbi kultúra kiszorulása } \\
\text { ingázás }\end{array}$ \\
\hline
\end{tabular}

Forrás: saját szerkesztés.

A faluban a mindennapi élet során némely esetekben a házasságkötés vagy közösségi élmények hatására enyhülni látszottak a különbözőségekből fakadó problémák. Azonban a közösségi eseményeken túl az együttélési nehézségek továbbra is fennmaradtak és meghatározták a faluban élök kapcsolatait (Kiss 2005).

A 1. táblázatban felsorolt társadalmi problémák a két településen eltérő jellegü konfliktusokat jelenítenek meg, amelyekben a lakosságra jellemző értékek is megjelennek.

Tinnyén a szegregált, lassabban fejlődő falu biztosítja a kultúrák keveredését, fokozatos frissítését, ugyanakkor a családi kapcsolódásaik, hagyományaik miatt nehezebben érvényesülnek a beköltözők a társadalmi, politikai életben. A lakosságában fokozatosan gyarapodó község számára a szuburbanizációs folyamatok mind a régi mind pedig az új lakosok számára meghatározták a mindennapi életet. Bár jelen vannak azok a szegregációs jelenségek, amelyek mind történetileg, mind földrajzilag, infrastrukturálisan vagy társadalmilag meghatározzák a közösségi kapcsolatokban rejlő problémákat, mégis kialakul a társadalmi együttélés. Egyre jobban összefonódott a régi és az új lakosok kultúrája, szokásai. Az ófaluban épülő új házak lakói újfajta szemléletet vittek a falu régi negyedeibe, kulturális hatást gyakorolva rájuk. Azonban nemcsak az új betelepültek hoztak változást a régi lakosok életében, hanem az ófalú lakóinak viselkedéskultúrája is hatott az újonnan betelepülőkére. A korábban betelepülök között már vizsgálható volt a két kultúra összefonódása. A legjellemzőbb összekötő kapocs közöttük a globális vagy környezeti kultúra (Molnár 2005). 
Budajenőn a gazdag, kényelmes elővárosi luxusnegyedek kialakulása, az ingázás, a modernizáció előtérbe helyezése miatt a hagyományos kultúra eltünőben van értékrendszerével együtt. A rekreációs szuburbán település konfliktusai nem az együtt élő, hanem az egymás mellett élő népesség problémáit mutatják be. A beköltöző lakosok a földterületi vitákban, a vállalkozásaik lehetőségeinek teret követelve szorítják ki a régi kultúrát, hagyományokat. Nincs törekvésük a falusi életbe bekapcsolódni, társas kapcsolataik és munkájuk által továbbra is a városhoz kötődnek. Az elővárosi élet számukra kikapcsolódás, ugyanakkor jellemző rájuk az erős érdekérvényesítés képessége (Vasárus 2017). Az eltérő intenzitású migrációs folyamatok meghatározzák a szuburbán településeken a helyi társadalom kapcsolathálózatát, kulturális életét, társadalmi berendezkedését. A több évtizedes történelmi sajátosságok, a faluvezetési stratégiák, az anyagi források, földrajzi tényezők mind hozzájárultak a szuburbanizációt kísérő szegregációs és migrációs jelenségekhez.

\section{Összegzés}

A tanulmányban Magyarország térszerkezeti változásait vizsgáló szakirodalmakon keresztül mutatom be a rendszerváltás utáni szuburbanizációs folyamatok által meghatározott lokális konfliktusokat a nyertes szuburbán településeken.

A szuburbanizáció során manifesztálódott társadalmi konfliktusok már a korábbi évtizedek által történelmileg is meghatározottak voltak, melyeket bővítettek azok az új problémakörök, amelyek a térbeli átalakulás következményeiként jelentkeztek (Csurgó 2013). A települések nem voltak felkészülve a szuburbanizációs folyamatokat kísérő jelentősebb szegregációs és migrációs jelenségeket követő lokális problémáknak a kezelésére. A településeken kialakuló feszültségek tükrözik a gazdasági és hatalmi érdekek előtérbe helyezését a helyi érdekekkel, kultúrával szemben. A zöldterületek felszámolása, vállalatok benyomulása, a területek beépítése, a magántulajdon terjeszkedése mind fokozza a társadalmi egyenlötlenségeket.

A rendszerváltás után Budapest agglomerációjában lévő településeken nem egyformán zajlottak a kiköltözések (Gergely 2014). A nagyobb és gazdagabb ingatlanok tulajdonosai a magas presztízsü külvárosi településekre költöztek. Még az egymás melletti településeken is megfigyelhetőek voltak az eltérő gyorsasággal megvalósuló térfolyamatok. Míg egyik település nagyon népszerü volt a kiköltözők között (Budajenő), főleg a gazdagabbak által kedveltek, addig a közvetlen szomszéd települést kevésbé választották a kiköltözők (Tinnye). A települések eltérő fejlettségi szintet képviseltek elsősorban gazdasági és infrastrukturális szinten, amelyeket befolyásoltak a különböző vezetési stratégiák is. Tinnyén a település vezetöi lassították a kiköltözés folyamatát, míg Budajenőn nem tulajdonítottak nagyobb jelentőséget a helyiek gyors kiszoruló kultúrájának, a konfliktusok kezelésének.

A szuburbanizáció nyertes településein a helyi lokális problémák megjelenítik a konfliktusokat átható új értékváltozásokat is. A konfliktushelyzetek mögött megjelenő elsődleges prioritást élvező új társadalmi értékek, mint a gazdagság értéke, a kényelmes és egészséges életmódra való törekvés értéke, amelyek elsősorban a nyertes rekreációs szuburbán településeken mutatkoznak. A megjelenő új társadalmi értékek szociokulturális vonatkozásában vizsgálva ezeket a falvakat, nem jelenthetjük ki egyértelmüen azt, hogy 
nyertesei a szuburbanizációs folyamatoknak. Az elővárosi településeken, ahol a bevándorlások gyorsan zajlanak, várható a tradicionális élet teljes átalakulása, a régi lakosok hagyományos kultúrájának kiszorulása.

A településeken a fokozatosan vagy teljesen kiszoruló kulturális értékek által meghatározott problémák elemzése során vizsgálandó kérdés az, hogy az új kulturális értékek, valamint a társadalom által kívánatosnak tartott értékek hogyan illeszkednek egymáshoz és miként tudnak meghonosodni az adott településeken.

\section{Irodalom}

Andorka Rudolf (2006) Bevezetés a szociológiába. Budapest: Osiris Kiadó.

Bajmóczy Péter (2014): A szuburbanizáció két évtizede Magyarországon. Északmagyarországi stratégiai füzetek, 9(2): 6-18.

Beluszky Pál - Sikos T. Tamás (2011): Változó falvaink. Tizenkét falurajz Kercaszomortól Nyírkarászig. Budapest: Akadémiai Kiadó.

Boros Julianna (2011): A települési szegregáció feltételezett okai és következményei. Acta Sociologica - Pécsi Szociológiai Szemle, 4(1): 97-111.

Csizmadia Zoltán (2014): A társadalmi konfliktusok kutatásának elméleti megalapozása - Új nézőpontok és kutatási irányok. Magyar Tudomány, 175(11): 1332-1344.

Csurgó Bernadett (2013): Vidéken lakni és vidéken élni. Budapest: Argumentum Kiadó.

Dövényi Zoltán - Kovács Zoltán (1999): A szuburbanizáció térbeni-társadalmi jellemzői Budapest környékén. Földrajzi Értesitó, 48(1-2): 33-57.

Enyedi György (1988): Településformáló folyamatok. Educatio, 2001(4): 663-669.

Enyedi György (1996): Regionális folyamatok Magyarországon. Budapest: Hilscher Rezső Szociálpolitikai Egyesület.

Gergely Júlia (2014): Településvezetés és szuburbanizáció. Tér és Társadalom, 28(4): 138-155.

Kiss Réka (2005): Migrációs folyamatok hatása Budajenő társadalmára. In Glatz Ferenc -

Schwartz Gyöngyi - Szarvas Zsuzsa - Szilágyi Miklós (szerk.): Utóparaszti hagyományok és modernizációs törekvések a magyar vidéken. Budapest: MTA

Néprajzi Kutatóintézet - MTA Társadalomkutató Központ, 243-255.

Koós Bálint (2020): Városi zsugorodás és lakóhelyi szegregáció az ezredforduló után. Tér és Társadalom, 34(1): 48-68.

Kondor Attila (2016): Helyi konfliktusok Budapest szuburbán zónájába. Földrajzi Közlemények. 140(3): 216-228.

Kovács Katalin (1999): Szuburbanizációs folyamatok a fóvárosban és a budapesti agglomerációban. In Barta, Györgyi - Beluszky Pál (szerk.): Társadalmi-gazdasági átalakulás a Budapesti agglomerációban. Budapest: Regionális Kutatási Alapítvány, 91-114. 
Kovács Zoltán (2017): Városok és urbanizációs kihívások Magyarországon. Magyar Tudomány, 178(3): 302-310.

Központi Statisztikai Hivatal: (2010) A változások tükrében Magyarország 1989-2009. Budapest: Központi Statisztikai Hivatal.

Molnár Mária (2005): A mindennapi élet konfliktusai Tinnyén a falusi lakosok és az újonnan betelepülök között. In Glatz Ferenc - Schwartz Gyöngyi - Szarvas Zsuzsa - Szilágyi Miklós (szerk.): Utóparaszti hagyományok és modernizációs törekvések a magyar vidéken. Budapest: MTA Néprajzi Kutatóintézet - MTA Társadalomkutató Központ, 231-241.

Schuchmann Júlia (2013): Lakóhelyi szuburbanizációs folyamatok a Budapesti agglomerációban. Doktori Értekezés.

Szirmai Viktória (2009): A várostérségi versenyképesség társadalmi tényezői. Hogyan lehetnek a magyar nagyvárosok versenyképesebbek? Pécs - Budapest: Dialóg Campus Kiadó.

Váradi Zsuzsanna - Szirmai Viktória (2012): Térbeli-társadalmi elkülönülés és integráció a magyar nagyváros-térségekben. In Kovách Imre - Dupcsik Csaba - P. Tóth Tamás Takács Judit (szerk.): Társadalmi integráció a jelenkori Magyarországon. Budapest: Argumentum Kiadó, 115-133.

Szirmai Viktória (2015): A magyar nagyváros-térségek térbeli társadalmi jellegzetességei, a centrum-periféria modell átalakulása. In Szirmai Viktória (szerk.): A területi egyenlötlenségektől a társadalmi jól-lét felé. Székesfehérvár: Kodolányi János Főiskola, 147-166.

Timár Judit (1999): Elméleti kérdések a szuburbanizációról. Földrajzi értesitő, 48(1-2): 7-31.

Timár Judit - Váradi Mónika (2000): A szuburbanizáció egyenlőtlen területi fejlődése az 1990es évek Magyarországán. In Horváth Gyula - Rechnitzer János (szerk.): Magyarország területi szerkezete és folyamatai az ezredfordulón. Pécs: MTA Regionális Kutatások Központja, 153-175.

Timár Judit (2006): Az agglomerálódástól a szuburbanizációig: „tértermelés” a posztszocialista Magyarországon. In: Csapó Tamás - Kocsis Zsolt (szerk.): Agglomerációk és szuburbanizálódás Magyarországon. Konferenciakötet. Szombathely: Savaria University Press, 35-51.

Vasárus Gábor (2017): Külterületi szuburbanizáció és szegregáció. Példák vidéki agglomerációk konfliktusaira. Településföldrajzi Tanulmányok, 5(1): 84-94.

Valuch Tibor (2014): A rendszerváltás hatásai a magyar társadalom térbeliségére Metszetek, 2014(2): 110-118. 